\title{
TCOM \\ Listen to the audience(s)! Expectations and characteristics of expert debate attendants
}

\section{Nina Wicke and Monika Taddicken}

Abstract

Expert debates have become a popular form to inform the public about scientific issues. To deepen our knowledge about individuals who attend such formats and to investigate what they expect of the dissemination of science, this study analyzes the attendants of scientific expert debates and their expectations. Cluster analysis is applied to survey data $(n=358)$ to explore whether distinct segments may be distinguishable within this supposedly homogeneous audience. Four different segments were identified and, overall, the findings indicate that attendants expect science communication to not only present scientific findings comprehensibly and from different perspectives, but also to create everyday life applicability, whereas interacting with scientists is of less interest.

Keywords

DOI

Popularization of science and technology; Public perception of science and technology; Science and media

https://doi.org/10.22323/2.19040202

Submitted: 27th January 2020

Accepted: 20th July 2020

Published: 17th August 2020

Introduction

Scientific knowledge is relevant to many aspects of daily life. However, scientific findings can reveal complex relationships, so it is challenging for laypeople to make sense of them [Fischhoff and Scheufele, 2013; Schäfer, Kristiansen and Bonfadelli, 2015]. Therefore, science communication is considered important for individuals and of high societal relevance, as it fosters greater public understanding of science and scientific methods [Burns, $\mathrm{O}^{\prime}$ Connor and Stocklmayer, 2003]. Different approaches of science communication exist such as the deficit model [Bodmer, 1985], predicting that perceptions of science would improve after increasing the knowledge about science. In recent years, however, various science communication formats have been established, often based on current science communication developments such as 'eventification' and public engagement [Fähnrich, 2017]. Instead of one-way communication, they involve a two-way exchange of information between scientists and their audience [Bucchi, 2008]. Among these formats which have risen in popularity are dialogue-oriented forms such as science cafés, science festivals, events such as "Science on Tap" and 
"Meet the Scientist", science speed dating, consensus conferences and Citizen Science projects [e.g., Altay and Lakhlifi, 2020; Dijkstra, 2017; Rose et al., 2017]. These formats often take place in a casual setting such as a café or a bar [Ocobock and Hawley, 2020] and provide multiple levels of engagement through different dissemination and dialogue forms such as lectures, discussions, workshops, and lab experiments, for example [Canovan, 2019; Fogg-Rogers et al., 2015]. All of these events try to connect scientists with the public in order to bring science physically and intellectually closer to laypeople.

An example of a well-established dialogue-oriented format are expert debates. These aim to inform the public about scientific issues and encourage a fact-based discussion between experts and laypeople. Expert debates offer different scientific perspectives, especially for controversial topics. Further, they can help laypeople form opinions of scientific findings and can advise on how to use these findings in everyday actions [Bromme and Thomm, 2016]. Experts can thus empower laypeople to make informed decisions and can include the audience in the discussion as well as enable their interests or questions to be taken into account. Expert debates are a well-known and prevalent format, which take place regularly on various topics. In Germany, such public events are attended occasionally by $14 \%$ of the population and frequently by $10 \%$ [Wissenschaft im Dialog, 2018]. Therefore, this study focuses specifically on this science communication format.

Thus far, there have been few studies on the efficacy and the effects of dialogue-oriented formats; for instance, regarding enhancements on public understanding and knowledge, scientific literacy, or perception of science. These studies show that formats such as debates, science cafés, and science festivals may inspire interest and curiosity, as well as stimulate discussion and engagement through informal learning processes [Bultitude and Sardo, 2012; Dijkstra, 2017; Jensen and Buckley, 2014]. Further, these formats can improve perceptions of science [Boyette and Ramsey, 2019; Canovan, 2019] and attitudes towards scientific topics [Altay and Lakhlifi, 2020]. The audience often values the opportunity to interact with scientific researchers [Jensen and Buckley, 2014; Sardo and Grand, 2016], which can also be a great predictor of positive learning outcomes [Wiehe, 2014]. Although these formats have the ambition of broadening the reach of science, they seem to have appealed particularly to what are known as 'Sciencephiles' [Schäfer, Füchslin et al., 2018]: an audience that mostly already has a positive view of science [Bultitude and Sardo, 2012; Kennedy, Jensen and Verbeke, 2018; Ocobock and Hawley, 2020]. However, we do not as of yet fully know why these people are better reached by science communication.

Although it is important to broaden the audience of science communication and to increase overall reach [Humm, Schrögel and Leßmöllmann, 2020], the relevance of the existing audiences should not be neglected; these are the core supporters of science in society and they should be kept interested. Research on the audiences of science communication in general shows that the highly interested audience are mostly people with a broad information repertoire, positive attitudes towards science, a high level of scientific literacy, and a high level of education [Guenther and Weingart, 2018; Guenther, Weingart and Meyer, 2018; Jarreau and Porter, 2018; Metag, Füchslin and Schäfer, 2015; Metag, Maier et al., 2018; Schäfer, Füchslin et al., 2018; Taddicken and Reif, 2016]. However, as the formats differ, the audience may differ as well. Presently, changes in media environments and the diversification of 
science communication formats allows individuals to use the kinds of information and media channels they are specifically looking for and, in turn, can lead to more diverse information patterns and more heterogeneous audiences. As Scheufele $[2018$, p. 1123$]$ points out, " $[\mathrm{t}]$ he idea that there is not a single, monolithic public when it comes to science communication [...] has long become a truism". To gain a better (theoretical) understanding of science communication's audiences, their differences and similarities should be investigated in greater detail [Scheufele, 2018]. Therefore, this study analyzes the audience(s) of a German science communication format, a series of expert debates. This format was created with the aim of introducing scientific facts and a variety of scientific perspectives into societal debates and to promote dialogue between science and the public. Among the issues being discussed have been 'digitalized childhood', 'organ donation', 'geoengineering' and 'artificial intelligence', for example.

Therefore, focus is given to the audience's expectations of 'good' communication. Previous studies have shown that expectations regarding the media coverage of issues such as the refugee debate [Arlt and Wolling, 2018] or climate change [Taddicken and Wicke, 2019] and nanotechnology [Maier et al., 2016; Milde and Barkela, 2016] differ individually [for an overview see Voigt, 2016]. However, systematic investigations regarding science communication are scarce: we know neither what quality expectations the audience has nor how the use of different science communication formats affects this. We assume that the individuals' ideas, desires and expectations of the dissemination of science can motivate their levels of engagement with science communication [Feather, 1982]. Formats that suit the quality expectations of the audience may have the potential to increase the interest in, and understanding of, scientific issues. In contrast, disappointments and dissatisfaction could lead to non-usage [Wolling, 2009]. Following this, as it is in journalism, the audience of science communication should be "a highly important point of reference" [Loosen and Schmidt, 2012, p. 873]. The audience is influential when it comes to deciding what kind of information is of importance and to produce content that will be noticed [Weischenberg, Malik and Scholl, 2012]. So far, there is little evidence to suggest what the audience expects from science communication content. To avoid disregarding the audience as well as their needs and interests [Fischhoff, 2013], their expectations need to be explored. Therefore, this study offers a deep dive into the specific segment of the population who attend expert debates, adding the novelty of taking their expectations into account.

In order to investigate the audience(s) of an expert debate, a quantitative survey followed by a segmentation analysis is applied. This method helps to divide the population or specific audiences into "homogeneous, mutually exclusive subgroupings" [Hine et al., 2014, p. 442] and identifies relevant and interesting audience segments for further research [e.g., Burns and Medvecky, 2018]. The findings can be useful as guidance to practitioners, to help facilitate the tailoring of communication campaigns regarding specific topics to this specific audience(s) [e.g., Hefner, 2013; Slater, 1996], to avoid an "aiming at everybody and reaching nobody" approach [Felt, 2003, p. 39], and to modify events according to audience expectations. 
Expectations of science communication
To raise the understanding of the (different) audiences of science communication, their expectations regarding science communication should be considered. A theoretical approach that tries to explain (media) usage from an audience's qualitative perspective by taking their expectations into account - the Theory of Subjective Quality Assessment [TSQA; Wolling, 2004; Wolling, 2009] — is applied here in the context of a science communication format.

\subsection{The Theory of Subjective Quality Assessment}

The TSQA is based on the assumption that usage decisions depend on the evaluation of different characteristics of a media product. Wolling [2004; 2009] assumes that individuals have quality expectations of certain features of media products which are related to their motives for use. Previous research has shown that they have an idea about what constitutes appropriate means for the dissemination of science and scientific findings [Maier et al., 2016; Milde and Barkela, 2016]. Those expectations can also be linked to (usage) experiences from the past, which can then lead to expectations varying between individuals. In general, these expectations refer to specific characteristics the audience desires for the format (both stylistic and content).

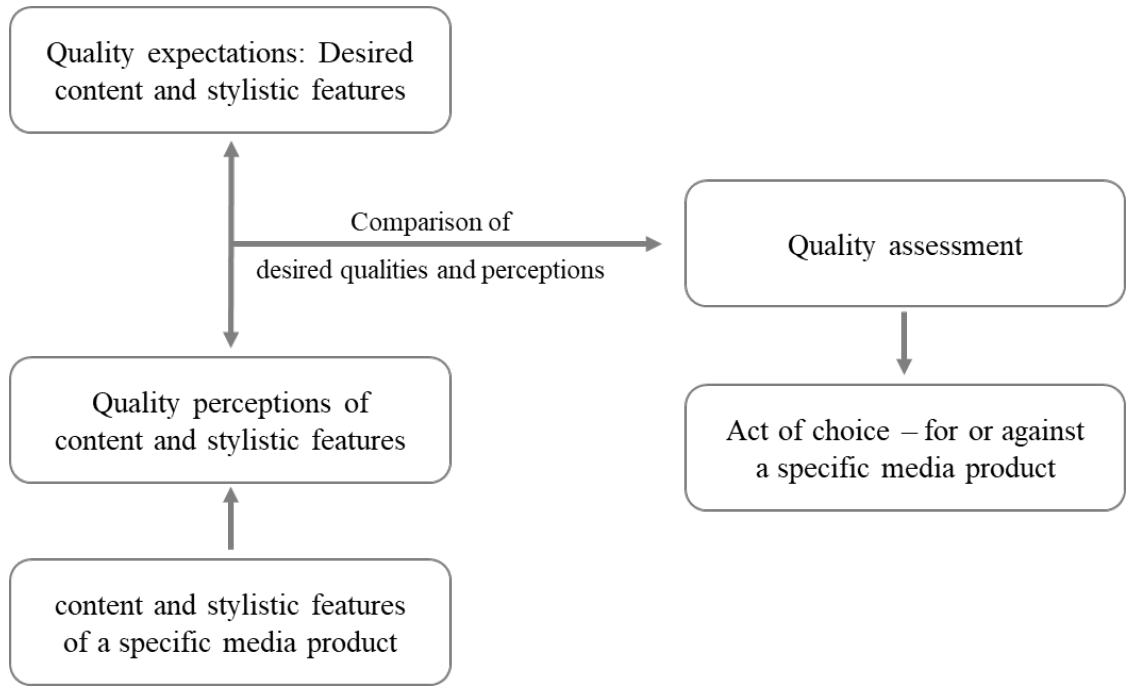

Figure 1. Theory of Subjective Quality Assessment [based on Wolling, 2004, p. 175; Wolling, 2009, p. 88].

The perception of these features, and thus of the quality of a debate, is an integral part of the reception process, which affects the quality of the assessment. This assessment is understood as a subjective construction process and is constituted on the basis of comparing quality expectations and quality perceptions. If people perceive their expectations of a specific characteristic as fulfilled, then they are assumed to have a positive assessment of the format. Thus, the more these expectations are satisfied, the more likely the format will be used by the audience [Wolling, 2004]. If expectations are not met, dissatisfaction may arise towards the format or science communication in general, and there may be no future use of the format. Therefore, the quality of a communication format not only depends on its characteristics but also on the balance of expectations and perceptions of the audience. 
We adapt this approach of media quality assessments to a science communication format, and more specifically to a live expert debate. Thus, we transfer it to non-mediated communication, although the investigated format has also been streamed online. To understand the quality assessment and the use of a science communication format from an audience's point of view, their expectations must be considered. To explore these, we ask:

RQ1: What does the audience of the science communication format "expert debate" expect of the dissemination of science and scientific findings?

\subsection{The audience(s) of science communication and their expectations}

So far, we know little about the audience's expectations of science communication. Previous studies have mainly focused on the evaluations of various formats such as TV programmes and different reporting features [de Cheveigné and Véron, 1996; Maier et al., 2016; Milde, 2009; Milde and Barkela, 2016; Vowe and Wolling, 2004; Wolling, 2004]. Furthermore, special surveys such as the German and Swiss Science Barometer [Wissenschaft im Dialog, 2019; WissensCHaftsbarometer Schweiz, 2019] evaluated whether the public feels informed about science, for example. However, studies have typically only investigated the assessments and not considered expectations. As assessments are influenced by expectations [Wolling, 2009], it is difficult to explain why the public has assessed different science communication forms in the way they have.

Drawing on Wolling's [2009] approach, expectations regarding science communication can relate to different elements and aspects. Wolling [2009] suggests to first explore these features by means of focus groups or guided interviews in which people discuss media formats. Within qualitative studies of German audiences' expectations of the media coverage about scientific issues such as climate change [Taddicken and Wicke, 2019] and nanotechnology [Maier et al., 2016; Milde and Barkela, 2016], different features of the media's content and reporting style were identified. The findings of these studies can relate to expectations of the communication of science in general as well as to expert-laypeople communication. For example, it was particularly important to the audience that scientific content is explained in a comprehensible and descriptive way, as it is often highly abstract, complex, uncertain, and therefore difficult to understand. Furthermore, previous research on the communication of scientific experts has shown that laypeople value comprehensibility and that they want to be able to understand these experts [Milde, 2009; Taddicken, Wicke and Willems, 2020]. Thus, the comprehensibility of complex scientific issues is an expectation regarding the dissemination of science. The audience expects scientific findings to be more contextualized by experts, which provides them with a greater level of orientation [Taddicken and Wicke, 2019]. Moreover, considering scientific issues, it is difficult to form one's own opinion. The presentation of the diversity of scientific perspectives to show which disciplines and institutions are involved in researching the topic was considered helpful for evaluating the credibility of research findings and to better understand the scientific issue [Taddicken and Wicke, 2019]. In addition, this presentation might actually increase the understanding of how science works. As laypeople are usually not familiar with scientific research processes and methods, they expect it to be explained. Furthermore, it was expected that 
science communication addresses both the uncertainty and contradictoriness of scientific findings, as they are seen as characteristics of science [Taddicken and Wicke, 2019]. However, previous research on indivividuals' expectations of media coverage have reported this uncertainty as inconsistent. For example, some prefer to be informed about the current state of research and uncertainties to also be pointed out, while others explicitly do not want to be informed about uncertain research findings which they regard as a sign of an incomplete research process [Maier et al., 2016; Milde and Barkela, 2016; Taddicken and Wicke, 2019]. Another aspect which is part of the expectations of the audience is the everyday applicability of the scientific issue. Related to the abstractness and complexity of science, it might be difficult for individuals to recognize and understand the importance of the topic for their daily lives. Thus, they hope for examples to illustrate the 'practical applicability'. For instance, laypeople expected to receive clear recommendations for their individual behaviour in order to mitigate climate change [Taddicken and Wicke, 2019]. Moreover, science communicators are developing new formats to increase participation and dialogue as a majority of citizens would like to become more involved in decision-making processes about science and technology [Eurobarometer, 2013; PES: Durant, 1999; Irwin and Wynne, 1996]. Therefore, individuals may also expect to begin a dialogue with scientific experts.

We assume that people differ in their expectations regarding these features, which leads to differentiated quality assessments of science communication formats. Accordingly, taking those expectations into account helps to explain how and why formats such as an expert debate are assessed positively or negatively and used. Moreover, as we assume that people differ in their expectations of science communication, this study further explores whether distinct segments may be distinguishable within the audience of the investigated science communication format.

Usually, science communication users are identified as people with a high interest in, high knowledge of, and positive attitudes towards science [Füchslin, Schäfer and Metag, 2018; Guenther, Weingart and Meyer, 2018; Guenther and Weingart, 2018; Jarreau and Porter, 2018; Schäfer, Füchslin et al., 2018]. They are highly supportive of science and believe it is important to be informed, using a broad range of media and information sources. Metag, Füchslin and Schäfer [2015] and Taddicken and Reif [2016] show further that those who inform themselves about, for example, climate change through different (online) media and seek frequent information about the topic tend to be most concerned about the environment.

In addition to expectations, the assessments of dialogue-oriented science communication formats, motives for attending, as well as interest and knowledge, have yet to be extensively researched. To deepen our knowledge about individuals who inform themselves about scientific issues and who are interested in science, such as the 'Sciencephiles' [Schäfer, Füchslin et al., 2018] or the 'Science Consumers' [Metag, Maier et al., 2018], we explore and segment the audience of an expert debate in a second step. In conclusion, we are interested in:

RQ2: Which audience segments can be identified with regard to their expectations of science communication within the audience of a scientific expert debate? 
To investigate the expectations of an expert debate's audience, a German format created in 2016 was researched. This format is oriented towards a "classic" expert debate but gives particular importance to a diversification of perspectives and interactivity. The aim of the format is to introduce scientific facts and a variety of scientific perspectives into societal debates and to promote dialogue between science and the public. It seeks to offer comprehensible scientific information on current controversial scientific topics. For this purpose, the expert debate takes place regularly in various German cities. The debates are free of charge and open to the general public, with no invitation or registration needed in order to encourage attendance. They take place within mostly traditional venues on Thursday evenings at 7pm and last 90 minutes. The discussion always includes three experts from different scientific disciplines and two moderators. Every debate is streamed live over various mediums such as a YouTube channel, and the homepage of a German media partner. During the 90-minute discussion, the audience can ask questions in the event via question cards and through social media. On average, around 100 people have attended these debates.

\subsection{Data and sample}

The present study draws on data from a quantitative paper-pencil survey. Data collection happened between February 2018 and June 2019 at seven different expert debates in the German cities of Berlin and Braunschweig. Debated topics included digitalized childhood, organ donation, the housing market, geoengineering, human intelligence, artificial intelligence, and cannabis.

The participants were asked to complete the survey's first part before the debate and the second part after. The total number of surveys collected varied between the debates, due to the number of attendants varying between events and because participation was voluntary. A self-selected sample of $n=358$ was obtained. It consisted of $44.6 \%$ male and $55.4 \%$ female, all aged between 16 and 87 (average: 38.1 years), and $49.5 \%$ have an academic degree (see Table 1 ).

\subsection{Measurements and data analysis}

The survey was divided into two parts (see Table 3 in appendix A, for detailed information). First, before the debate, the participants were asked about their motives for attending, their level of interest, personal involvement, and knowledge regarding the issue under discussion. Following this, information about their interest in science and in scientific issues, as well as socio-demographics, were collected. Moreover, to be able to compare the audience with findings of other (segmentation) studies on science communication audiences, the pre-questionnaire contained variables to analyze participants' science-related information behaviour. Furthermore, previous research has shown that science-related information behaviour is related to perceptions of science: Those who regularly have contact with scientific information through media have more positive attitudes, higher knowledge about science and a higher scientific literacy [Guenther and Weingart, 2018; Jarreau and Porter, 2018; Metag, Maier et al., 2018]. Thus, we also measured the perceptions of science and scientific knowledge. 
Table 1. Socio-demographic overview of the sample.

\begin{tabular}{|l|r|}
\hline Gender \\
\hline Female & $55.4 \%$ \\
Male & $44.6 \%$ \\
\hline Age & $37.3(18.1)$ \\
\hline $10-19$ & $6.2 \%$ \\
$20-29$ & $41.5 \%$ \\
$30-39$ & $15.9 \%$ \\
$40-49$ & $8.3 \%$ \\
$50-59$ & $9.7 \%$ \\
$60+$ & $18.3 \%$ \\
\hline Education & $7.2 \%$ \\
\hline Certificate of Secondary Education ${ }^{1}$ & $32.6 \%$ \\
Higher Education Entrance Certification & \\
Academic Degree & $49.5 \%$ \\
Doctorate Degree (PhD) & $6.9 \%$ \\
Other & $3.6 \%$ \\
\hline Note. $\mathrm{n}=358$. & \\
${ }^{1}$ Haupt-/Volksschulabschluss and Mittlere Reife/Realschulabschluss. \\
2 Fachhochschulreife and Abitur.
\end{tabular}

In addition to these variables, we considered the expectations of the audiences regarding the dissemination of science and their importance, following the assumptions of the TSQA [Wolling, 2009]. Accordingly, six items were developed based on the findings of the preceding group discussions on quality expectations regarding media coverage of scientific issues [Maier et al., 2016; Milde and Barkela, 2016; Taddicken and Wicke, 2019]. These six items refer to the comprehensibility of complex scientific issues, the presentation of the diversity of scientific perspectives, an explanation of the research processes and methods, and communication of the uncertainty of scientific knowledge. Moreover, expectations regarding the meaning of science in daily life and the possibility of beginning a dialogue with experts were also measured.

The second part of the survey investigated the assessments of the debate and the debating experts. Moreover, the participants were asked whether their expectations were fulfilled or not, based on the six items used in the first part of the survey. In addition, the participants evaluated on whether their level of knowledge regarding the debated issue and scientific processes had increased.

In order to answer the aforementioned research questions, statistical analysis of the data was conducted. Included were descriptions of the frequency distributions and mean value comparisons. In a second step, we used the methodological approach of segmentation studies [e.g., Hine et al., 2014; Schäfer, Füchslin et al., 2018; Slater, 1996]. Cluster analysis is a proven and established method of identifying different audience segments [Mahrt, 2017]. Here, a hierarchical cluster analysis using Ward's method (squared Euclidian distance), based on a theoretically guided, psychographic approach, was conducted [Metag and Schäfer, 2018]. The six items of expectations were used as discriminating variables within the cluster analysis. 
To determine the number of segments, distance coefficients (elbow criterion) and a dendrogram plot were used to indicate the best solution. Four clusters were identified and validated by discriminant analysis. This analysis yielded an $87.2 \%$ rate of correctly classified cases. We also applied a k-means clustering algorithm which supported our decision to look more closely at the four-cluster solution ( $\mathrm{K}=$ 0.493; $\mathrm{p}<0.001$ ). We then compared both four-cluster solutions based on Ward's method and k-means clustering. As there is no agreed upon definition of what a "true" cluster is [Hennig, 2015], we argued from a theoretical perspective that the more meaningful categorization with higher dissimilarities between the four clusters provides interesting findings for the scientific community and praxis of science communication. For this reason, we base our cluster description on the four-cluster solution by Ward. Analyses of variance (ANOVA), as well as post-hoc tests (Scheffé), were conducted to identify significant differences.

\section{Results}

\subsection{The audience of the expert debate and their expectations (RQ1)}

Focusing on the audience's expectations (see Table 2), it becomes evident that the attendants of the expert debates hope for an understandable explanation of the debated issues and an identification of the perspectives of different scientific disciplines. Besides a comprehensive and multi-perspectival approach to scientific issues, the attendants also appreciate knowing how the research is applicable in everyday life, and having uncertainties pointed out. The audience is not only interested in scientific findings and their application, but also in background information about processes and methods to understand how scientific findings are obtained. However, their expectation of beginning a dialogue with scientific experts is, comparably, rather low. Overall, the audience has high expectations regarding the dissemination of science and its findings in the context of an expert debate.

Table 2. Expectations of the audience.

\begin{tabular}{|l|c|c|c|}
\hline Items & $\mathrm{n}$ & $\mathrm{M}$ & $\mathrm{SD}$ \\
\hline Expectations (1= "do not agree at all" to 5= "strongly agree") & 334 & 4.62 & 0.69 \\
\hline In the expert debate. . & 334 & 4.57 & 0.65 \\
\hline ... complex scientific content should be explained comprehensibly. & 336 & 4.38 & 0.75 \\
\hline ... different scientific perspectives should be made clear. & 331 & 4.36 & 0.80 \\
\hline ... an everyday applicability of scientific research should be pointed out. & 333 & 4.21 & 0.99 \\
\hline ...the uncertainty of scientific findings should be addressed. & 329 & 3.91 & 1.00 \\
\hline ... how scientific findings are obtained should be communicated. & & \\
\hline ... the experts should be given feedback on their research from citizens. & &
\end{tabular}

Comparing the different events (see Table 4 in appendix A), the six expectations regarding the dissemination of science within an expert debate did not vary by much. Although the topics differed in their characteristics such as controversy, proximity to everyday life, interdisciplinarity and media presence, the importance ascribed by the attendants to each dimension does not seem to be influenced by the debated topic. Thus, the audience's expectations of science communication are not issue-specific, but remain consistent. 
Individuals grouped into the four segments identified within the cluster analysis differ not only in expectations but also in their information behaviour, perceptions, interests, and knowledge of science and scientific issues. They also differed in their motives for attending an expert debate and regarding the evaluation of the fulfilment of their expectations (see Table 5 in appendix A). We will examine these differences more closely below.

1. The first cluster is named "The Topic Interested" ( $\mathrm{n}=21,6.5 \%)$. It forms the smallest segment of the audience, compared to the other segments, and it contains the least females. On average, those in this cluster are 43 years old and have Abitur (school leaving certificate in Germany, equivalent to A-levels) or an academic degree. The expectations of "The Topic Interested" regarding the dissemination of science within the format of expert debate are lower than of the other segments and they scored the lowest on all items regarding fulfilment of their expectations. This segment wants complex, abstract scientific issues to be explained in a comprehensible way and applicability to everyday life made clear. Least expected from them is information about how scientific knowledge is gained, which is in line with their stated low-level interest in the working methods of scientists and the scientific system. In general, "The Topic Interested" rarely attend events and only occasionally use mass media for information about science-related topics. This corresponds to their low interest in scientific issues. However, their motivation to attend the expert debates stems from self-informing about the debated issue. They seem to be more interested in the issue and less interested in science. Furthermore, they would like to form their own opinions and are fairly interested in having a dialogue with the experts and other participants and are the segment with the most "Other" answers regarding their motives. This could be an indication that they were not primarily there for themselves, but were 'dragged along' by a friend or partner. "The Topic Interested" strongly believe that science improves our future and they consider it to be important in their lives. Although they question the objectivity of the scientific findings, and do not agree that scientific results can be considered certain, they believe that scientific knowledge is the best source for reliable knowledge.

2. "The Well-Informed Spectators" ( $\mathrm{n}=96,29.9 \%)$ are the second largest audience segment and are mostly female. Their expectations of the dissemination of science within the format are mixed: they would like complex content to be understandable, but do not particularly expect scientific processes and methods to be explained. Correspondingly, they are not very interested in research processes and the scientific system, but are interested in the debated issue and scientific issues in general. They highly expect an everyday applicability of the research to be pointed out. Compared to the other segments, this one feels most personally concerned. However, "The Well-Informed Spectators" did not take part in the debate because they wanted to form an opinion. Interestingly, their motivation to attend the expert debate as a pastime and to be entertained was comparatively high. Moreover, they inform themselves about science often and, in particular, through online communication. They may feel well-informed, related to the fact that they 
consider their previous knowledge to be particularly high regarding the debated issue. Nevertheless, individuals in this segment most often stated that they had learned something about the topic. In terms of perceptions of science, they believe the most that it is important to know about science in everyday life and that science improves all of our lives.

3. The largest segment is formed by "The Science Advocates" ( $\mathrm{n}=131,40.8 \%$ ). With an average age of 45 years, this segment is the oldest and has the highest number of females. In addition, they score highest on all expectations regarding the format. Thus, they have high demands for what goals science communication should achieve. In particular, those who are part of this segment expect scientific uncertainties to be presented and require comprehensible explanations of scientific content. They also expect that researchers will be given feedback by citizens. Individuals belonging to this cluster mainly use mass media to inform themselves about science, followed by online communication. Their interest in science - in scientific issues, the working methods of scientists and the scientific system - is the highest. Along with this, they stated that they came to the event to gain insight into research processes and to follow a controversial discussion between scientists. "The Science Advocates" believe in future progress through science and that scientific knowledge is reliable. Interestingly, despite their high expectations, they were the most satisfied with the debate.

4. "The Appreciative Listeners" ( $\mathrm{n}=73,22.7 \%)$ are the youngest segment and the most highly educated. Their expectations regarding the format are not as high as those of "The Science Advocates", but are still extremely high. Comprehensibility is most important for them and their motivation to engage with scientists is low. In line with this, this segment was the least interested in interaction processes and attended in order to be entertained. They assess their prior topic knowledge as average and would like to learn about the issue and research processes. Thus, their main interest is not beginning a dialogue with scientists and exchanging views with others, but rather to understand science. In comparison with the other segments, they rarely attend such events and do not inform themselves much about science-related issues, although their interest in science is quite high. As with all other segments, "The Appreciative Listeners" think knowing about science is important for their everyday life. Although they believe in future progress through science, they would be sceptical, however, if life indeed became healthier, easier, and more comfortable because of it. They believe most of all that scientific knowledge is reliable, but are aware of scientific uncertainty.

This study aimed to shed light on the little researched issue of audience's expectations regarding science communication. For this, we investigated the attendants of a live expert debate format. According to the Theory of Subjective Quality Assessment [Wolling, 2004; Wolling, 2009], we examined audience's expectations and explored the importance of different features of this science communication format.

Overall, the audience shows high expectations. Comprehensibility and, in particular, a multi-perspective view of science are of high importance. These 


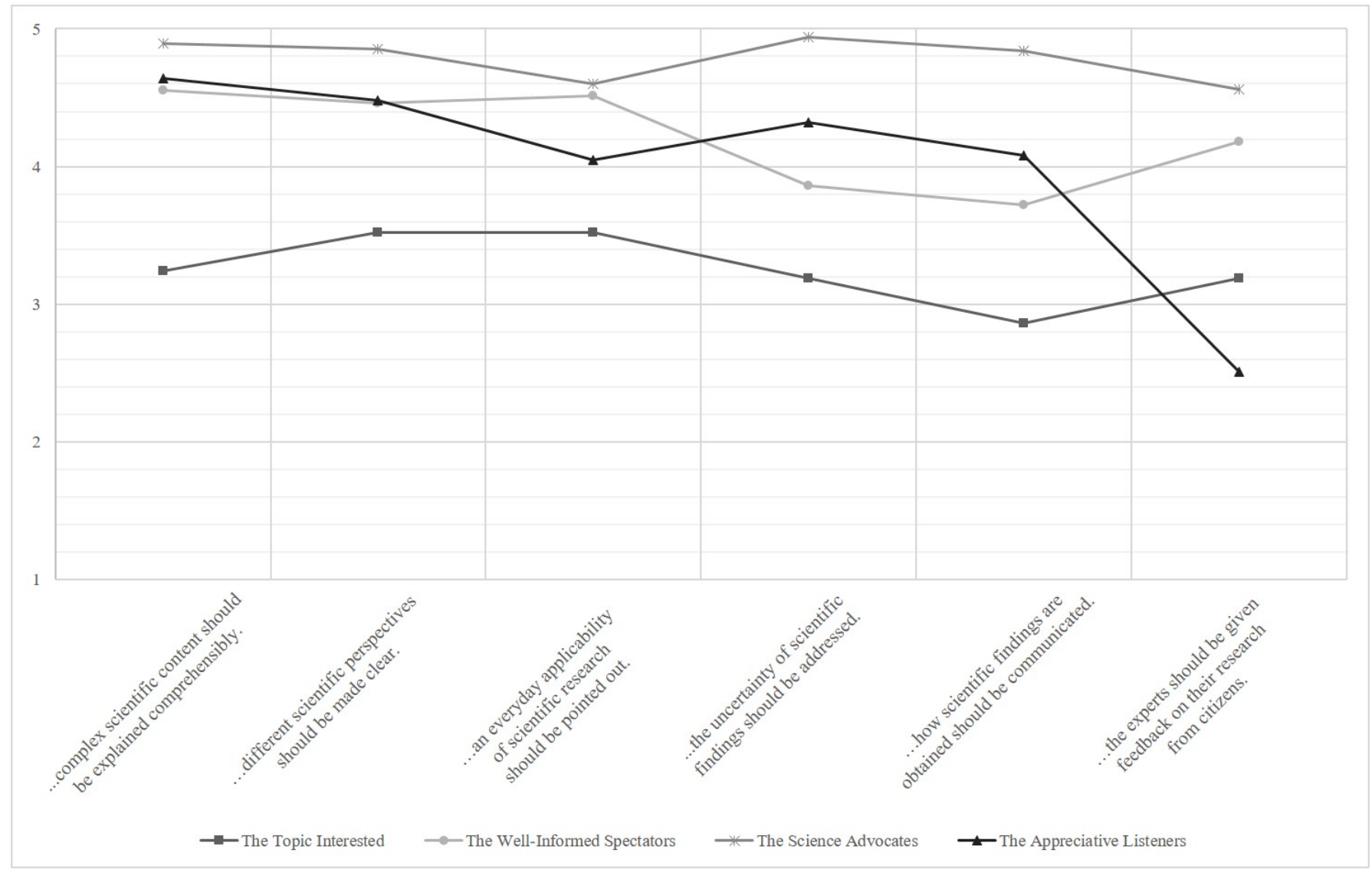

Figure 2. Segments of the expert debates' audience.

findings also reflect the communicator's perspective on the aims of science communication. According to Siggener Kreis ${ }^{1}$ [Wissenschaft im Dialog, 2014], one main function of science communication is the comprehensible dissemination of knowledge. As stated by the study's participants, the possibility of beginning a dialogue with scientific experts is of less interest compared to the other expectations. This is an interesting finding, considering the paradigm shift away from the assumption of an information and competence deficit among citizens, the so-called "deficit model" [Bauer, 2016; Bucchi, 2008], which shapes the paradigm of a Public Understanding of Science [PUS; Bodmer, 1985] to the model of a Public Engagement of Science [PES; Durant, 1999; Irwin and Wynne, 1996]. According to the latter (PES), the participation of citizens should be strengthened through direct interactions with scientists and their involvement in scientific processes.

Considering the expectations of the participants in this research, their main interest, and their main motivation to attend the debate, is not dialogue but rather to understand science and gain knowledge. This is an aim which is also shared by, for example, some visitors of science festivals, as explored in previous studies [e.g., Fogg-Rogers et al., 2015; Jensen and Buckley, 2014]. However, before beginning a dialogue, laypeople need to feel permitted to engage with scientific issues. From this perspective, the attendants' wish to gain knowledge and information could be understood as an 'enabler for engagement'. Thus, the distinction between Public Understanding and Public Engagement should not be understood as a dichotomy.

\footnotetext{
${ }^{1}$ The Siggener Kreis is a supra-institutional working group of science communicators, scientists and science journalists dealing with the further development of science communication in Germany.
} 
Comprehensibility is a basic prerequisite for effectively examining scientific content. To achieve clear communication, experts are often advised to use less jargon [Bullock et al., 2019; Sharon and Baram-Tsabari, 2013; Taddicken, Wicke and Willems, 2020] and more of the language of laypeople [Zimmermann and Jucks, 2018]. For instance, experts' comprehensibility is assessed positively when they draw connections between science and the everyday world of the audience [Taddicken, Wicke and Willems, 2020], which is also demanded by the attendants of the expert debate. These findings can also be linked to previous research about (science) journalism and its quality criteria [e.g., Anhäuser and Wormer, 2012; Rögener and Wormer, 2017]. For example, citizens expect media coverage to be accurate, unbiased, independent, and to present a diversity of viewpoints. Media should enable them to develop their own opinions [van der Wurff and Schoenbach, 2014]. These similarities are understandable as tasks and functions ascribed to journalism, such as information transfer, education, criticism and control, which strongly correspond to tasks ascribed to science communication. In journalism, similar to the field of science, laypeople only have vague ideas of the work processes. Therefore, news media should not only be transparent in their work, but also respond to audience complaints and demands [Urban and Schweiger, 2014; van der Wurff and Schoenbach, 2014] as should experts and science communication in general.

Exploring the characteristics of the participants in our study, we can see they have an above-average interest in science and scientific issues compared to the German and Swiss populations [Wissenschaft im Dialog, 2018; Wissenschaft im Dialog, 2019; WissensCHaftsbarometer Schweiz, 2019], similar to Swiss "Sciencephiles" [Schäfer, Füchslin et al., 2018]. This interest may have led them to attend such a debate and to actively engage with scientific content. Potentially also related to their high interest, they inform themselves about scientific issues more than the average German through scientific events and the mass media, whereas their online usage behaviour is average [Wissenschaft im Dialog, 2018]. Regarding the perceptions of science, the attitudes of the expert debates' audiences are more positive. For example, they score higher on the perceived importance of science for their daily life and are more convinced that science makes our lives better [Wissenschaft im Dialog, 2018]. This finding can be related to previous research, showing that people who come in contact with information about science frequently show more positive attitudes in general [Guenther and Weingart, 2018; Metag, Maier et al., 2018], though it has been unable to confirm any causality effects. However, considering these individuals use science communication and are willing to make the effort of attending a live event, it is interesting that their belief in the objectivity of scientific knowledge is comparably low. All in all, this study confirms that science communication formats such as expert debates largely attract highly interested and highly educated people with positive attitudes towards science [Bultitude and Sardo, 2012; Canovan, 2019; Jarreau and Porter, 2018; Kennedy, Jensen and Verbeke, 2018; Metag, Maier et al., 2018; Ocobock and Hawley, 2020; Schäfer, Füchslin et al., 2018].

Focusing on the expectations, we wanted to explore whether the audience can be categorized into various segments. Although the audience of scientific expert debates might be assumed as homogeneous, we believe it to be plausible to also assume differences, especially with regard to people's expectations. Our cluster analysis identified four different segments: "The Topic Interested", "The Well-Informed 
Spectators", "The Science Advocates" and "The Appreciative Listeners". We discovered some nuanced differences between them in that, in contrast to the other segments, "The Science Advocates" are quite interested in scientific processes and expect an expert debate to explain scientific methods and uncertainties. "The Well-Informed Spectators" and "The Appreciative Listeners" are interested in research processes as well, but prefer comprehensible explanations of the debated issues. All segments disagree on the importance of beginning a dialogue with the experts. However, "The Appreciative Listeners" are little interested in giving feedback to them. While the innovative strength and importance of science in everyday life is acknowledged by all four segments, their science-related information behaviour differs slightly. "The Well-Informed Spectators" lean more toward online media use while the others lean more towards traditional mass media. "The Topic Interested" inform themselves comparably less and their attendance was predominantly motivated by their interest in the debated issue. However, they assessed the expert debate rather negatively and it is questionable as to whether they would attend future events.

In summary, our findings indicate that the audience of an expert debate is not a homogeneous, monolithic public, but one in which differences between attendants exist. We assume this to be transferable to other science communication formats as well.

\subsection{Limitations and outlook}

These findings must be confirmed in future studies as this study has some limitations. First, the sample is self-selected and neither representative regarding the German population at large nor a full census of the audience.

Another limitation relates to the items used to measure information behaviour. Due to the limited scope, only a small number of information sources were included in the questionnaire. In following studies, the media and information behaviour should be measured in greater detail and at the level of concrete formats. Also, the scale to measure the perceptions of science should be streamlined and should ideally consist of standard, established items guided by a theoretical framework to standardize more segmentation analyses [Füchslin, Schäfer and Metag, 2018; Füchslin, 2019].

Finally, the results of this study are limited to the audience of only one science communication format; the audience of another format could be comprised of different individuals. Therefore, the next stage could be to compare these findings and the audiences of different science communication formats. For example, those who live-streamed the expert debate (the online audience) did not taken part in this study. It might be interesting to know the extent to which this audience resembles the characteristics of those in the live event. Moreover, different and similar (media) formats as well as (cultural) environments could be included in a comparison. Selection and usage processes among individuals could also be investigated, i.e., how people use and select science communication formats such as an expert debate. Expectations are not only important for reach and attention. Further questions concern how people process the (debated) scientific content; for example, with regard to their knowledge and attitudes, and interpersonal communication following the event. In this context, the role of opinion leaders 
[Schäfer and Taddicken, 2015] and whether or not they are part of the audience could be identified.

In future research, the investigation of expectations should be elaborated on and could be further adapted to specific science communication formats or scientific issues as little is known regarding these. The findings about the audience's expectations contribute to a better understanding of differentiated quality assessments and, thereby, the use of science communication. Applying qualitative methods to detail the quantitative findings of segmentations could be helpful to explore those expectations and assessments in more depth. These can also be included in discussions about quality standards and evaluation processes in science communication. The conception and implementation of science communication formats could become more effective and inclusive and the number of uses could increase if the expectations of individuals are considered fulfilled.

\subsection{Conclusion}

Thus far, scarce are studies that have contributed to a better (theoretical) understanding of science communication's audiences, their reasons for using and attending formats, and the value this holds. Attendance at an expert debate is an under-studied activity. Thus, this study broadens the knowledge about the specific segment of the population which attends such forms of science communication. It confirms previous research about the science communication audience characteristics in terms of education, information behaviour, and perceptions, but also shows interesting findings regarding their relatively low interest in engaging with scientists, motives and overall expectations. The audiences' expectations are not dependent on the debated issue. Furthermore, the attendants have a general idea about how science should be disseminated. Science communication should not only present new scientific findings, but also place them in context, create an applicability to people's everyday life, provide information on research methods, and explain uncertainties.

These insights on the characteristics of the expert debate's audience and its segments provided by this study are also valuable for the practice of science communication. Participants' assessments of the debates were rather low as their expectations were not sufficiently met. Therefore, science communicators may need to further develop ways of disseminating science, for example, by making scientific processes more transparent and enabling laypeople to gain insight into scientific research as well as to better understand how scientific findings are obtained. Another implication could be that experts should communicate in a more comprehensible way and show how their research can be used in everyday life. We believe this will empower laypeople to apply scientific findings in their decisions and daily behaviour, something still rarely done, as we have shown.

Furthermore, we showed that even the participants of our study rarely attend such events. The question now is how science communicators can better reach these people, especially those who are quite interested in the issues but not in science, even though they are only a small percentage of the audience. One measure could be to take greater account of the expectations and motives for attending the event when advertising. For instance, those who inform themselves on a regular basis 
online, "The Well-Informed Spectators", were a large segment of the audience. As such, in the future, it might be useful to draw more attention to online communication to reach those individuals.

In general, to research the audience seems promising and has the potential to expand our understanding of the use of science communication as well as to broaden the scholarly discussion in this field. One of the greatest challenges science communication faces is to reach a broad audience. Raising the understanding of how scientific issues and research findings should be disseminated from the perspective of the audience may help to develop appropriate means and effective ways of science communication, and therefore deserves further attention in future research.

Conflict of interest. The Authors declare that they have no conflict of interest.

Acknowledgments This study was part of the science communication format "The Debate" (https://www.die-debatte.org/). This project was carried out in cooperation between Wissenschaft im Dialog, the Science Media Center Germany, and the TU Braunschweig. It was funded by the Volkswagen Foundation (reference number: 92 741), the Klaus Tschira Stiftung, and the Stifterverband 2016-2018. We thank all these partners for their support as well as the anonymous reviewers for their helpful and constructive feedback.

Appendix A.

Table 3. Pre-Post-Questionnaire (in excerpts).

Supplementary material

Part 1

\begin{tabular}{|c|c|c|}
\hline & $\mathrm{n}$ & $\%$ \\
\hline to inform myself or increase my knowledge & 288 & $26.7 \%$ \\
\hline to gain insight into scientific research & 175 & $16.2 \%$ \\
\hline in order to form an opinion & 142 & $13.2 \%$ \\
\hline to follow a controversial debate & 139 & $12.9 \%$ \\
\hline in order to be entertained & 75 & $7.0 \%$ \\
\hline to exchange views with others on the debated issue & 72 & $6.7 \%$ \\
\hline to be able to make (everyday) decisions & 67 & $6.2 \%$ \\
\hline as a pastime & 40 & $3.7 \%$ \\
\hline to ask experts questions & 39 & $3.6 \%$ \\
\hline to share my views and experiences with experts & 21 & $1.9 \%$ \\
\hline other & 20 & $1.9 \%$ \\
\hline
\end{tabular}

\begin{tabular}{|l|c|c|c|}
\hline \multicolumn{1}{|c|}{} & $\mathrm{n}$ & $\mathrm{M}$ & $\mathrm{SD}$ \\
\hline Interest, personal concern and knowledge regarding the debated issue (1= "very low" to 5= "very high") \\
\hline Interest in the debated issue & 356 & 4.35 & 0.71 \\
\hline Personal concern regarding the debated issue & 345 & 3.78 & 1.10 \\
\hline Knowledge about the debated issue & 346 & 3.09 & 0.92 \\
\hline Interest in science (1= "do not agree at all" to 5= "strongly agree") & 327 & 4.40 & 0.75 \\
\hline I am very interested in scientific issues.
\end{tabular}


Table 3. Continued from the previous page.

\begin{tabular}{|c|c|c|c|}
\hline I am very interested in the scientific system. & 320 & 3.73 & 1.12 \\
\hline I am very interested in the working methods of scientists. & 321 & 3.73 & 1.12 \\
\hline \multicolumn{4}{|c|}{$\begin{array}{l}\text { Information behaviour: How often do you use the following information sources to inform yourself about sci- } \\
\text { entific issues? (1= "never" to 5= "very often") }\end{array}$} \\
\hline Mass media such as television programmes or newspaper articles & 335 & 3.70 & 1.09 \\
\hline $\begin{array}{l}\text { Online communication and social media } \\
\text { (e.g., Facebook, Twitter, blogs) }\end{array}$ & 334 & 3.21 & 1.40 \\
\hline Scientific information events (e.g., discussions) & 336 & 2.82 & 1.16 \\
\hline \multicolumn{4}{|l|}{ Perceptions of science ( $1=$ "do not agree at all" to $5=$ "strongly agree") } \\
\hline It is important for me to know about science in everyday life. & 339 & 4.30 & 0.87 \\
\hline Science makes our lives healthier, easier and more comfortable. & 329 & 3.75 & 0.92 \\
\hline Science offers better opportunities for future generations. & 336 & 4.38 & 0.73 \\
\hline The function of science is to determine the truth. & 324 & 3.97 & 1.11 \\
\hline There is more than one right answer to most scientific questions. & 330 & 3.93 & 1.04 \\
\hline If scientists have worked carefully, their results can be considered as certain. & 337 & 3.58 & 1.04 \\
\hline Scientific knowledge is the most objective form of knowledge. & 327 & 3.83 & 0.96 \\
\hline Scientific knowledge is the best source for reliable knowledge. & 339 & 4.15 & 0.90 \\
\hline \multicolumn{4}{|l|}{ Expectations (1= "do not agree at all" to 5= "strongly agree") } \\
\hline ...complex scientific content should be explained comprehensibly. & 334 & 4.62 & 0.69 \\
\hline ... different scientific perspectives should be made clear. & 334 & 4.57 & 0.65 \\
\hline ...how scientific findings are obtained should be communicated. & 336 & 4.38 & 0.75 \\
\hline ...the uncertainty of scientific findings should be addressed. & 331 & 4.36 & 0.80 \\
\hline ... an everyday applicability of scientific research should be pointed out. & 333 & 4.21 & 0.99 \\
\hline ...the experts should be given feedback on their research from citizens. & 329 & 3.91 & 1.00 \\
\hline \multicolumn{4}{|l|}{ Part 2} \\
\hline & $\mathrm{n}$ & $\mathrm{M}$ & SD \\
\hline \multicolumn{4}{|l|}{ Assessments of the expert debate ( $1=$ "do not agree at all" to $5=$ "strongly agree") } \\
\hline comprehensible & 321 & 4.40 & 0.72 \\
\hline descriptive & 310 & 3.84 & 0.95 \\
\hline balanced & 312 & 3.55 & 1.10 \\
\hline entertaining & 311 & 3.84 & 0.94 \\
\hline helpful & 310 & 3.70 & 1.03 \\
\hline close to everyday life & 316 & 3.77 & 1.06 \\
\hline profound & 312 & 3.56 & 1.00 \\
\hline \multicolumn{4}{|l|}{ Fulfilled expectations ( $1=$ "do not agree at all" to $5=$ "strongly agree") } \\
\hline ... complex scientific content was explained comprehensibly. & 316 & 3.67 & 1.01 \\
\hline ... different scientific perspectives were made clear. & 318 & 3.61 & 1.10 \\
\hline ...how scientific findings are obtained was communicated. & 315 & 2.84 & 1.15 \\
\hline ... the uncertainty of scientific findings was addressed. & 311 & 3.29 & 1.20 \\
\hline ... an everyday applicability of scientific research was pointed out. & 316 & 3.65 & 1.06 \\
\hline ... the experts were given feedback on their research from citizens. & 293 & 2.68 & 1.16 \\
\hline \multicolumn{4}{|l|}{ Knowledge (1= "do not agree at all" to $5=$ "strongly agree") } \\
\hline The expert debate has taught me something about the debated issue. & 323 & 3.72 & 1.12 \\
\hline The expert debate has taught me something about scientific research processes. & 318 & 2.65 & 1.22 \\
\hline \multicolumn{4}{|l|}{ M: arithmetic mean; SD: standard deviation } \\
\hline
\end{tabular}


Table 4. Expectations of the audience according to the topics debated.

\begin{tabular}{|c|c|c|c|c|c|c|c|}
\hline & $\begin{array}{c}\text { Digitalized } \\
\text { childhood } \\
(\mathrm{n}=110)\end{array}$ & $\begin{array}{c}\text { Organ } \\
\text { donation } \\
(n=33)\end{array}$ & $\begin{array}{l}\text { Housing } \\
\text { market } \\
(n=29)\end{array}$ & $\begin{array}{c}\text { Human } \\
\text { intelligence } \\
(n=56)\end{array}$ & $\begin{array}{l}\text { Geoengi- } \\
\text { neering } \\
(n=22)\end{array}$ & $\begin{array}{c}\text { Artificial } \\
\text { Intelligence } \\
(n=19)\end{array}$ & $\begin{array}{c}\text { Cannabis } \\
(\mathrm{n}=68)\end{array}$ \\
\hline & $\begin{array}{c}\mathrm{M} \\
(\mathrm{SD})\end{array}$ & $\begin{array}{c}\mathrm{M} \\
(\mathrm{SD})\end{array}$ & $\begin{array}{c}\mathrm{M} \\
(\mathrm{SD})\end{array}$ & $\begin{array}{c}\mathrm{M} \\
(\mathrm{SD})\end{array}$ & $\begin{array}{c}\mathrm{M} \\
(\mathrm{SD})\end{array}$ & $\begin{array}{c}\mathrm{M} \\
(\mathrm{SD})\end{array}$ & $\begin{array}{c}\mathrm{M} \\
(\mathrm{SD})\end{array}$ \\
\hline \multicolumn{8}{|c|}{ Expectations $(1=$ "do not agree at all" to $5=$ "strongly agree") } \\
\hline \multicolumn{8}{|c|}{ In the expert debate... } \\
\hline $\begin{array}{l}\text {...complex } \\
\text { entific } \\
\text { should be explained } \\
\text { comprehensibly. }\end{array}$ & $\begin{array}{c}4.64 \\
(0.63)\end{array}$ & $\begin{array}{c}4.55 \\
(0.94)\end{array}$ & $\begin{array}{c}4.83 \\
(0.38)\end{array}$ & $\begin{array}{c}4.59 \\
(0.71)\end{array}$ & $\begin{array}{c}4.59 \\
(0.80)\end{array}$ & $\begin{array}{c}4.60 \\
(0.65)\end{array}$ & $\begin{array}{c}4.53 \\
(0.84)\end{array}$ \\
\hline $\begin{array}{l}\text {... different } \\
\text { entific perspectives } \\
\text { should be made } \\
\text { clear. }\end{array}$ & $\begin{array}{c}4.65 \\
(0.58)\end{array}$ & $\begin{array}{c}4.48 \\
(0.71)\end{array}$ & $\begin{array}{c}4.55 \\
(0.63)\end{array}$ & $\begin{array}{c}4.55 \\
(0.69)\end{array}$ & $\begin{array}{c}4.55 \\
(0.60)\end{array}$ & $\begin{array}{c}4.55 \\
(0.70)\end{array}$ & $\begin{array}{c}4.37 \\
(0.76)\end{array}$ \\
\hline $\begin{array}{l}\text {...an everyday } \\
\text { applicability of } \\
\text { scientific research } \\
\text { should be pointed } \\
\text { out. }\end{array}$ & $\begin{array}{c}4.55 \\
(0.63)\end{array}$ & $\begin{array}{c}4.44 \\
(0.80)\end{array}$ & $\begin{array}{c}4.41 \\
(0.50)\end{array}$ & $\begin{array}{c}4.16 \\
(0.97)\end{array}$ & $\begin{array}{c}4.27 \\
(0.94)\end{array}$ & $\begin{array}{c}4.26 \\
(0.73)\end{array}$ & $\begin{array}{c}4.53 \\
(0.61)\end{array}$ \\
\hline $\begin{array}{l}\ldots \text { the uncertainty } \\
\text { of scientific find- } \\
\text { ings should be } \\
\text { addressed. }\end{array}$ & $\begin{array}{c}4.37 \\
(0.86)\end{array}$ & $\begin{array}{c}4.36 \\
(0.70)\end{array}$ & $\begin{array}{c}4.24 \\
(0.74)\end{array}$ & $\begin{array}{c}4.18 \\
(0.94)\end{array}$ & $\begin{array}{c}4.57 \\
(0.60)\end{array}$ & $\begin{array}{c}4.53 \\
(0.68)\end{array}$ & $\begin{array}{c}4.21 \\
(0.80)\end{array}$ \\
\hline $\begin{array}{l}\text {...how scientific } \\
\text { findings are ob- } \\
\text { tained should be } \\
\text { communicated. }\end{array}$ & $\begin{array}{c}4.09 \\
(1.10)\end{array}$ & $\begin{array}{c}4.09 \\
(1.03)\end{array}$ & $\begin{array}{c}4.17 \\
(0.81)\end{array}$ & $\begin{array}{c}4.34 \\
(0.90)\end{array}$ & $\begin{array}{c}4.27 \\
(0.88)\end{array}$ & $\begin{array}{c}4.36 \\
(0.87)\end{array}$ & $\begin{array}{c}4.16 \\
(0.90)\end{array}$ \\
\hline $\begin{array}{l}\text {...the experts } \\
\text { should be given } \\
\text { feedback on their } \\
\text { research } \\
\text { citizens. }\end{array}$ & $\begin{array}{c}4.03 \\
(1.02)\end{array}$ & $\begin{array}{c}4.03 \\
(0.86)\end{array}$ & $\begin{array}{c}4.07 \\
(0.88)\end{array}$ & $\begin{array}{c}3.56 \\
(1.15)\end{array}$ & $\begin{array}{c}3.77 \\
(0.92)\end{array}$ & $\begin{array}{c}3.99 \\
(0.90)\end{array}$ & $\begin{array}{c}3.63 \\
(1.01)\end{array}$ \\
\hline
\end{tabular}

Table 5. Description of the audience segments.

\begin{tabular}{|c|c|c|c|c|}
\hline & $\begin{array}{l}\text { The Topic } \\
\text { Interested } \\
(\mathrm{n}=21,6.5 \%)\end{array}$ & $\begin{array}{c}\text { The Well- } \\
\text { Informed } \\
\text { Spectators } \\
(\mathrm{n}=96,29.9 \%)\end{array}$ & $\begin{array}{l}\text { The Science } \\
\text { Advocates } \\
(\mathrm{n}=131,40.8 \%)\end{array}$ & $\begin{array}{c}\text { The } \\
\text { Appreciative } \\
\text { Listeners } \\
(\mathrm{n}=73,22.7 \%)\end{array}$ \\
\hline & M & $\mathrm{M}$ & M & M \\
\hline \multicolumn{5}{|c|}{ Expectations of an expert debate ( 1 = "strongly disagree" to $5=$ "strongly agree") } \\
\hline $\begin{array}{l}\text {...complex scientific content } \\
\text { should be explained comprehens- } \\
\text { ibly. }\end{array}$ & $3.24^{\mathrm{a}}$ & $4.55^{\mathrm{b}}$ & $4.89^{\mathrm{c}}$ & $4.64^{\mathrm{b}, \mathrm{c}}$ \\
\hline $\begin{array}{l}\text {... different scientific perspectives } \\
\text { should be made clear. }\end{array}$ & $3.52^{\mathrm{a}}$ & $4.46^{\mathrm{b}}$ & $4.85^{\mathrm{C}}$ & $4.48^{\mathrm{b}}$ \\
\hline $\begin{array}{l}\text {... an everyday applicability of sci- } \\
\text { entific research should be pointed } \\
\text { out. }\end{array}$ & $3.52^{\mathrm{a}}$ & $4.51^{\mathrm{c}}$ & $4.60^{\mathrm{c}}$ & $4.05^{\mathrm{b}}$ \\
\hline
\end{tabular}


Table 5. Continued from the previous page.

\begin{tabular}{|l|c|c|c|c|}
\hline $\begin{array}{l}\text {...the uncertainty of scientific find- } \\
\text { ings should be addressed. }\end{array}$ & $3.19^{\mathrm{a}}$ & $3.86^{\mathrm{b}}$ & $4.94^{\mathrm{d}}$ & $4.32^{\mathrm{c}}$ \\
\hline $\begin{array}{l}\ldots \text { how scientific findings are ob- } \\
\text { tained should be communicated. }\end{array}$ & $2.86^{\mathrm{a}}$ & $3.72^{\mathrm{b}}$ & $4.84^{\mathrm{c}}$ & $4.08^{\mathrm{b}}$ \\
\hline $\begin{array}{l}\ldots \text { the experts should be given feed- } \\
\text { back on their research from citizens. }\end{array}$ & $3.19^{\mathrm{b}}$ & $4.18^{\mathrm{c}}$ & $4.56^{\mathrm{d}}$ & $2.51^{\mathrm{a}}$ \\
\hline
\end{tabular}

Descriptive variables

\begin{tabular}{|c|c|c|c|c|}
\hline \multicolumn{5}{|c|}{ Information behaviour ( $1=$ "never" to $5=$ "very often") } \\
\hline $\begin{array}{l}\text { Mass media such as television pro- } \\
\text { grammes or newspaper articles }\end{array}$ & 3.38 & 3.78 & 3.86 & 3.49 \\
\hline $\begin{array}{l}\text { Online communication and social } \\
\text { media (e.g., Facebook, Twitter, } \\
\text { blogs) }\end{array}$ & 2.95 & 3.65 & 2.98 & 3.11 \\
\hline $\begin{array}{l}\text { Scientific information events (e.g., } \\
\text { discussions) }\end{array}$ & 2.81 & 2.94 & 2.87 & 2.65 \\
\hline \multicolumn{5}{|c|}{ Perceptions of science ( $1=$ "do not agree at all" to $5=$ "strongly agree") } \\
\hline $\begin{array}{l}\text { It is important for me to know } \\
\text { about science in everyday life. }\end{array}$ & 4.10 & 4.34 & 4.33 & 4.22 \\
\hline $\begin{array}{l}\text { Science makes our life healthier, } \\
\text { easier and more comfortable. }\end{array}$ & 3.75 & 3.87 & 3.75 & 3.66 \\
\hline $\begin{array}{l}\text { Science offers better opportunities } \\
\text { for future generations. }\end{array}$ & 4.20 & 4.42 & 4.43 & 4.43 \\
\hline $\begin{array}{l}\text { The function of science is to determ- } \\
\text { ine the truth. }\end{array}$ & 3.90 & 4.02 & 4.10 & 3.70 \\
\hline $\begin{array}{l}\text { There is more than one right answer } \\
\text { to most scientific questions. }\end{array}$ & $3.35^{\mathrm{a}}$ & $3.86^{\mathrm{a}, \mathrm{b}}$ & $4.14^{\mathrm{b}}$ & $3.93^{\mathrm{a}, \mathrm{b}}$ \\
\hline $\begin{array}{l}\text { If scientists have worked carefully, } \\
\text { their results can be considered as } \\
\text { certain. }\end{array}$ & 3.25 & 3.46 & 3.76 & 3.56 \\
\hline $\begin{array}{l}\text { Scientific knowledge is the most ob- } \\
\text { jective form of knowledge. }\end{array}$ & 3.45 & 3.83 & 3.88 & 3.83 \\
\hline $\begin{array}{l}\text { Scientific knowledge is the best } \\
\text { source for reliable knowledge. }\end{array}$ & 4.10 & 4.17 & 4.16 & 4.20 \\
\hline \multicolumn{5}{|l|}{ Interest } \\
\hline $\begin{array}{l}\text { Interest in scientific issues } \\
(1=\text { "strongly disagree" to } 5= \\
\text { "strongly agree") }\end{array}$ & $3.71^{\mathrm{a}}$ & $4.40^{\mathrm{b}}$ & $4.50^{\mathrm{b}}$ & $4.47^{\mathrm{b}}$ \\
\hline $\begin{array}{l}\text { Interest in the scientific system } \\
(1=\text { "strongly disagree" to } 5= \\
\text { "strongly agree") }\end{array}$ & $2.80^{\mathrm{a}}$ & $3.68^{\mathrm{b}}$ & $3.90^{\mathrm{b}}$ & $3.73^{\mathrm{b}}$ \\
\hline $\begin{array}{l}\text { Interest in the working methods of } \\
\text { scientists }(1=\text { "strongly disagree" to } \\
5=\text { "strongly agree") }\end{array}$ & $2.70^{\mathrm{a}}$ & $3.59^{\mathrm{b}}$ & $3.99^{\mathrm{b}}$ & $3.81^{b}$ \\
\hline $\begin{array}{l}\text { Interest in the topic } \\
(1=\text { "not at all" to } 5=\text { "very much") }\end{array}$ & 4.48 & 4.39 & 4.42 & 4.25 \\
\hline $\begin{array}{l}\text { Personal concern } \\
(1=\text { "not at all" to } 5=\text { "very much") }\end{array}$ & 3.84 & 3.85 & 3.82 & 3.56 \\
\hline \multicolumn{5}{|l|}{ Knowledge } \\
\hline $\begin{array}{l}\text { Knowledge about the debated issue } \\
\text { before the debate } \\
(1=\text { "very low" to } 5=\text { "very high") }\end{array}$ & 3.19 & 3.27 & 3.02 & 2.99 \\
\hline
\end{tabular}


Table 5. Continued from the previous page.

\begin{tabular}{|c|c|c|c|c|}
\hline $\begin{array}{l}\text { The expert debate has taught me } \\
\text { something about the debated issue. } \\
(1=\text { "do not agree at all" to } 5= \\
\text { "strongly agree") }\end{array}$ & 3.10 & 3.80 & 3.79 & 3.71 \\
\hline $\begin{array}{l}\text { The expert debate has taught me } \\
\text { something about scientific research } \\
\text { processes. } \\
(1=\text { "do not agree at all" to } 5= \\
\text { "strongly agree") }\end{array}$ & 2.25 & 2.63 & 2.75 & 2.72 \\
\hline \multicolumn{5}{|l|}{ Motives (multiple answer question; \%) } \\
\hline $\begin{array}{l}\text { to inform myself or increase my } \\
\text { knowledge }(n=260)\end{array}$ & $32.6 \%$ & $27.2 \%$ & $25.0 \%$ & $28.6 \%$ \\
\hline $\begin{array}{l}\text { to follow a controversial debate } \\
(\mathrm{n}=126)\end{array}$ & $10.9 \%$ & $13.1 \%$ & $13.3 \%$ & $12.7 \%$ \\
\hline $\begin{array}{l}\text { to gain insight into scientific re- } \\
\text { search }(n=161)\end{array}$ & $6.5 \%$ & $16.2 \%$ & $18.7 \%$ & $15.5 \%$ \\
\hline in order to form an opinion $(n=126)$ & $15.2 \%$ & $10.7 \%$ & $13.8 \%$ & $14.1 \%$ \\
\hline to ask experts questions $(n=34)$ & $6.5 \%$ & $4.5 \%$ & $3.2 \%$ & $2.3 \%$ \\
\hline in order to be entertained $(n=69)$ & $2.2 \%$ & $8.3 \%$ & $5.6 \%$ & $9.5 \%$ \\
\hline $\begin{array}{l}\text { to be able to make (everyday) de- } \\
\text { cisions }(n=56)\end{array}$ & $4.3 \%$ & $5.2 \%$ & $6.3 \%$ & $5.9 \%$ \\
\hline $\begin{array}{l}\text { to share my views and experiences } \\
\text { with experts }(n=17)\end{array}$ & $6.5 \%$ & $2.1 \%$ & $1.5 \%$ & $0.9 \%$ \\
\hline $\begin{array}{l}\text { to exchange views with others on } \\
\text { the debated issue }(n=64)\end{array}$ & $6.5 \%$ & $5.2 \%$ & $8.3 \%$ & $5.5 \%$ \\
\hline as a pastime $(n=37)$ & $2.2 \%$ & $5.2 \%$ & $2.9 \%$ & $4.1 \%$ \\
\hline Other $(n=18)$ & $6.5 \%$ & $2.4 \%$ & $1.5 \%$ & $0.9 \%$ \\
\hline \multicolumn{5}{|c|}{ Fulfilled expectations ( $1=$ "do not agree at all" to $5=$ "strongly agree") } \\
\hline $\begin{array}{l}\text {...complex scientific content was } \\
\text { explained comprehensibly. }\end{array}$ & 3.16 & 3.56 & 3.76 & 3.79 \\
\hline $\begin{array}{l}\text {... different scientific perspectives } \\
\text { were made clear. }\end{array}$ & 3.10 & 3.53 & 3.67 & 3.70 \\
\hline $\begin{array}{l}\text {...how scientific findings are ob- } \\
\text { tained was communicated. }\end{array}$ & 2.63 & 2.82 & 2.88 & 2.96 \\
\hline $\begin{array}{l}\text {...the uncertainty of scientific find- } \\
\text { ings was addressed. }\end{array}$ & 2.78 & 3.17 & 3.43 & 3.32 \\
\hline $\begin{array}{l}\text {... an everyday applicability of sci- } \\
\text { entific research was pointed out. }\end{array}$ & 3.06 & 3.64 & 3.70 & 3.78 \\
\hline $\begin{array}{l}\text {... the experts were given feedback } \\
\text { on their research from citizens. }\end{array}$ & 2.50 & 2.85 & 2.79 & 2.42 \\
\hline \multicolumn{5}{|l|}{ Socio-demographic data } \\
\hline Year of Birth (M) & $1977.95^{a, b}$ & $1981.55^{\mathrm{a}, \mathrm{b}}$ & $1975.78^{a}$ & $1986.16^{b}$ \\
\hline Sex (female \%) & $40.0 \%$ & $59.6 \%$ & $60.3 \%$ & $47.2 \%$ \\
\hline $\begin{array}{l}\text { Education }(6=\text { Higher Education } \\
\text { Entrance Certification, } 7=\text { Aca- } \\
\text { demic Degree })\end{array}$ & 6.05 & 6.25 & 6.27 & 6.43 \\
\hline \multicolumn{5}{|c|}{$\begin{array}{l}\text { M: arithmetic mean. } \\
\text { Notes: analysis of variance: superscripts in the same row that differ indicate a significant difference } \\
\text { based on Scheffé post-hoc tests }(\mathrm{p}<0.05) \text {. }\end{array}$} \\
\hline
\end{tabular}


Altay, S. and Lakhlifi, C. (2020). 'Are science festivals a good place to discuss heated topics?' JCOM 19 (01), A07. https://doi.org/10.22323/2.19010207.

Anhäuser, M. and Wormer, H. (2012). 'A question of quality: criteria for the evaluation of science and medical reporting and testing their applicability'. In: Quality, honesty and beauty in science and technology communication. Proceedings of the $12^{\text {th }}$ International Public Communication of Science and Technology Conference. Ed. by B. Trench and M. Bucchi, pp. 335-337.

URL: http://www.medien-doktor.de/medizin/wp-content/uploads/sites/3 /downloads/2013/05/Paper-Florenz.pdf.

Arlt, D. and Wolling, J. (2018). ‘Bias wanted! Examining people's information exposure, quality expectations and bias perceptions in the context of the refugees debate among different segments of the German population'. Communications 43 (1), pp. 75-99. https://doi.org/10.1515/commun-2017-0045.

Bauer, M. W. (2016). 'Results of the essay competition on the 'deficit concept". Public Understanding of Science 25 (4), pp. 398-399. https://doi.org/10.1177/0963662516640650.

Bodmer, W. (1985). The public understanding of science. London, U.K.: Birkbeck College.

Boyette, T. and Ramsey, J. (2019). 'Does the messenger matter? Studying the impacts of scientists and engineers interacting with public audiences at science festival events'. JCOM 18 (02), A02. https://doi .org/10.22323/2.18020202.

Bromme, R. and Thomm, E. (2016). 'Knowing who knows: laypersons' capabilities to judge experts' pertinence for science topics'. Cognitive Science 40 (1), pp. 241-252. https://doi.org/10.1111/cogs. 12252.

Bucchi, M. (2008). 'Of deficits, deviations and dialogues: theories of public communication of science'. In: Handbook of Public Communication of Science and Technology. Ed. by M. Bucchi and B. Trench. London, U.K. and New York, U.S.A.: Routledge, pp. 57-76.

Bullock, O. M., Amill, D. C., Shulman, H. C. and Dixon, G. N. (2019). 'Jargon as a barrier to effective science communication: evidence from metacognition'. Public Understanding of Science 28 (7), pp. 845-853. https://doi.org/10.1177/0963662519865687.

Bultitude, K. and Sardo, A. M. (2012). 'Leisure and Pleasure: Science events in unusual locations'. International Journal of Science Education 34 (18), pp. 2775-2795. https: //doi .org/10.1080/09500693.2012.664293.

Burns, M. and Medvecky, F. (2018). 'The disengaged in science communication: how not to count audiences and publics'. Public Understanding of Science 27 (2), pp. 118-130. https://doi.org/10.1177/0963662516678351.

Burns, T. W., O'Connor, D. J. and Stocklmayer, S. M. (2003). 'Science Communication: A Contemporary Definition'. Public Understanding of Science 12 (2), pp. 183-202. https://doi .org/10.1177/09636625030122004.

Canovan, C. (2019). "“Going to these events truly opens your eyes". Perceptions of science and science careers following a family visit to a science festival'. JCOM 18 (02), A01. https://doi.org/10.22323/2.18020201.

de Cheveigné, S. and Véron, E. (1996). 'Science on TV: forms and reception of science programmes on French television'. Public Understanding of Science 5 (3), pp. 231-253. https://doi .org/10.1088/0963-6625/5/3/004.

Dijkstra, A. (2017). 'Analysing Dutch Science Cafés to better understand the science-society relationship'. JCOM 16 (01), A03.

https://doi.org/10.22323/2.16010203. 
Durant, J. (1999). 'Participatory technology assessment and the democratic model of the public understanding of science'. Science and Public Policy 26 (5), pp. 313-319. https://doi.org/10.3152/147154399781782329.

Eurobarometer (2013). Special Eurobarometer 401. Responsible Research and Innovation (RRI), Science and Technology. Brussels, Belgium: TNS Opinion \& Social on request of European Commission. URL: http://ec . europa. eu/commfr ontoffice/publicopinion/archives/ebs/ebs_401_en.pdf.

Fähnrich, B. (2017). 'Wissenschaftsevents zwischen Popularisierung, Engagement und Partizipation'. [Science events between popularization, engagement and participation]. In: Forschungsfeld Wissenschaftskommunikation. Ed. by H. Bonfadelli, B. Fähnrich, C. Lüthje, J. Milde, M. Rhomberg and M. S. Schäfer. Wiesbaden, Germany: Springer VS, pp. 165-182. https://doi.org/10.1007/978-3-658-12898-2_9.

Feather, N. T. (1982). 'Expectancy-value approaches: present status and future directions'. In: Expectations and actions: expectancy-value models in psychology. Ed. by N. T. Feather. Hillsdale, NJ, U.S.A.: Erlbaum.

Felt, U. (2003). Optimising public understanding of science and technology. Final report. Vienna, Austria. URL: https://sts.univie.ac.at/fileadmin/user_upl oad/i_sts/Forschung/Projekte_abgeschlossen/final_report_opus.pdf.

Fischhoff, B. (2013). 'The sciences of science communication'. Proceedings of the National Academy of Sciences 110 (Supplement 3), pp. 14033-14039. https://doi.org/10.1073/pnas.1213273110.

Fischhoff, B. and Scheufele, D. A. (2013). 'The science of science communication'. Proceedings of the National Academy of Sciences 110 (Supplement 3), pp. 14031-14032. https://doi .org/10.1073/pnas.1312080110. PMID: 23942127.

Fogg-Rogers, L., Bay, J. L., Burgess, H. and Purdy, S. C. (2015). “"Knowledge is power": a mixed-methods study exploring adult audience preferences for engagement and learning formats over 3 years of a health science festival'. Science Communication 37 (4), pp. 419-451. https://doi.org/10.1177/1075547015585006.

Füchslin, T. (2019). 'Science communication scholars use more and more segmentation analyses: can we take them to the next level?' Public Understanding of Science 28 (7), pp. 854-864. https: //doi .org/10.1177/0963662519850086.

Füchslin, T., Schäfer, M. S. and Metag, J. (2018). 'A short survey instrument to segment populations according to their attitudes toward science. Scale development, optimization and assessment'. Environmental Communication 12 (8), pp. 1095-1108. https://doi.org/10.1080/17524032.2018.1461673.

Guenther, L. and Weingart, P. (2018). 'Promises and reservations towards science and technology among South African publics: a culture-sensitive approach'. Public Understanding of Science 27 (1), pp. 47-58. https://doi.org/10.1177/0963662517693453.

Guenther, L., Weingart, P. and Meyer, C. (2018). "'Science is everywhere, but no one knows it": assessing the cultural distance to science of rural South African publics'. Environmental Communication 12 (8), pp. 1046-1061. https://doi.org/10.1080/17524032.2018.1455724. 
Hefner, D. (2013). “'Wie kriegen wir sie ins Boot?” Eine Typologie zur Entwicklung von Kommunikationsstrategien zur Förderung umweltschützenden Verhaltens'. ["How do we bring them in?" A typology of relevant characteristics and communication habits for developing communication strategies promoting environmentally sustainable behaviour]. Medien $\mathcal{E}$ Kommunikationswissenschaft 61 (3), pp. 387-405. https://doi .org/10.5771/1615-634x-2013-3-387.

Hennig, C. (2015). 'What are the true clusters?' Pattern Recognition Letters 64, pp. 53-62. https://doi.org/10.1016/j.patrec.2015.04.009.

Hine, D. W., Reser, J. P., Morrison, M., Phillips, W. J., Nunn, P. and Cooksey, R. (2014). 'Audience segmentation and climate change communication: conceptual and methodological considerations'. Wiley Interdisciplinary Reviews: Climate Change 5 (4), pp. 441-459. https://doi.org/10.1002/wcc. 279.

Humm, C., Schrögel, P. and Leßmöllmann, A. (2020). 'Feeling left out: underserved audiences in science communication'. Media and Communication 8 (1), pp. 164-176. https://doi.org/10.17645/mac.v8i1.2480.

Irwin, A. and Wynne, B. (1996). Misunderstanding Science? The Public Reconstruction of Science and Technology. Cambridge, U.K.: Cambridge University Press. https://doi .org/10.1017/cbo9780511563737.

Jarreau, P. B. and Porter, L. (2018). 'Science in the social media age: profiles of science blog readers'. Journalism \& Mass Communication Quarterly 95 (1), pp. 142-168. https://doi .org/10.1177/1077699016685558.

Jensen, E. and Buckley, N. (2014). 'Why people attend science festivals: interests, motivations and self-reported benefits of public engagement with research'. Public Understanding of Science 23 (5), pp. 557-573. https://doi.org/10.1177/0963662512458624.

Kennedy, E. B., Jensen, E. A. and Verbeke, M. (2018). 'Preaching to the scientifically converted: evaluating inclusivity in science festival audiences'. International Journal of Science Education, Part B 8 (1), pp. 14-21. https://doi.org/10.1080/21548455.2017.1371356.

Loosen, W. and Schmidt, J.-H. (2012). '(Re-)discovering the audience'. Information, Communication $\mathcal{E}$ Society 15 (6), pp. 867-887. https://doi.org/10.1080/1369118x.2012.665467.

Mahrt, M. (2017). 'Cluster analysis'. In: The international encyclopedia of communication research methods. Ed. by J. Matthes, C. S. Davis and R. F. Potter. Hoboken, NJ, U.S.A.: John Wiley \& Sons Inc., pp. 1-9. https://doi.org/10.1002/9781118901731.iecrm0025.

Maier, M., Milde, J., Post, S., Günther, L., Ruhrmann, G. and Barkela, B. (2016). 'Communicating scientific evidence: scientists', journalists' and audiences' expectations and evaluations regarding the representation of scientific uncertainty'. Communications 41 (3), p. 73. https://doi.org/10.1515/commun-2016-0010.

Metag, J., Füchslin, T. and Schäfer, M. S. (2015). 'Global warming's five Germanys: a typology of Germans' views on climate change and patterns of media use and information'. Public Understanding of Science 26 (4), pp. 434-451. https://doi.org/10.1177/0963662515592558.

Metag, J., Maier, M., Füchslin, T., Bromme, L. and Schäfer, M. S. (2018). 'Between active seekers and non-users: segments of science-related media usage in Switzerland and Germany'. Environmental Communication 12 (8), pp. 1077-1094. https://doi.org/10.1080/17524032.2018.1463924. 
Metag, J. and Schäfer, M. S. (2018). 'Audience segments in environmental and science communication: recent findings and future perspectives'. Environmental Communication 12 (8), pp. 995-1004.

https://doi.org/10.1080/17524032.2018.1521542.

Milde, J. and Barkela, B. (2016). 'Wie Rezipienten mit wissenschaftlicher Ungesichertheit umgehen: Erwartungen und Bewertungen bei der Rezeption von Nanotechnologie im Fernsehen'. [How recipients deal with scientific uncertainty: expectations and evaluations in the reception of nanotechnology on television]. In: Wissenschaftskommunikation zwischen Risiko und (Un-)Sicherheit. Ed. by G. Ruhrmann, L. Guenther and S. H. Kessler. Cologne, Germany: Herbert von Halem, pp. 193-211.

Milde, J. (2009). Vermitteln und Verstehen: Zur Verständlichkeit von Wissenschaftsfilmen im Fernsehen. [To communicate and to understand: on the comprehensibility of science films on television]. Wiesbaden, Germany: VS Verlag für Sozialwissenschaften. https://doi.org/10.1007/978-3-531-91630-9.

Ocobock, C. and Hawley, P. (2020). 'Science on tap: effective public engagement or preaching to the choir?' JCOM 19 (01), A04. https://doi.org/10.22323/2.19010204.

Rögener, W. and Wormer, H. (2017). 'Defining criteria for good environmental journalism and testing their applicability: an environmental news review as a first step to more evidence based environmental science reporting'. Public Understanding of Science 26 (4), pp. 418-433. https://doi.org/10.1177/0963662515597195.

Rose, K. M., Korzekwa, K., Brossard, D., Scheufele, D. A. and Heisler, L. (2017). 'Engaging the public at a science festival: findings from a panel on human gene editing'. Science Communication 39 (2), pp. 250-277. https://doi.org/10.1177/1075547017697981.

Sardo, A. M. and Grand, A. (2016). 'Science in culture: audiences' perspective on engaging with science at a summer festival'. Science Communication 38 (2), pp. 251-260. https://doi.org/10.1177/1075547016632537.

Schäfer, M. S. and Taddicken, M. (2015). 'Mediatized opinion leaders: new patterns of opinion leadership in new media environments?' International Journal of Communication 9, pp. 960-981.

URL: https://ijoc.org/index.php/ijoc/article/view/2778/1351.

Schäfer, M. S., Füchslin, T., Metag, J., Kristiansen, S. and Rauchfleisch, A. (2018). 'The different audiences of science communication: a segmentation analysis of the Swiss population's perceptions of science and their information and media use patterns'. Public Understanding of Science 27 (7), pp. 836-856. https://doi.org/10.1177/0963662517752886.

Schäfer, M. S., Kristiansen, S. and Bonfadelli, H. (2015).

'Wissenschaftskommunikation im Wandel. Relevanz, Entwicklung und Herausforderungen des Forschungsfeldes'. In: Wissenschaftskommunikation im Wandel. Ed. by M. S. Schäfer, S. Kristiansen and H. Bonfadelli. Cologne, Germany: Herbert von Halem Verlag, pp. 10-42.

Scheufele, D. A. (2018). 'Beyond the choir? The need to understand multiple publics for science'. Environmental Communication 12 (8), pp. 1123-1126. https://doi.org/10.1080/17524032.2018.1521543. 
Sharon, A. J. and Baram-Tsabari, A. (2013). 'Measuring mumbo jumbo: A preliminary quantification of the use of jargon in science communication'. Public Understanding of Science 23 (5), pp. 528-546. https://doi.org/10.1177/0963662512469916.

Slater, M. D. (1996). 'Theory and method in health audience segmentation'. Journal of Health Communication 1 (3), pp. 267-284. https://doi.org/10.1080/108107396128059.

Taddicken, M. and Reif, A. (2016). 'Who participates in the climate change online discourse? A typology of Germans' online engagement'. Communications 41 (3), pp. 315-337. https://doi.org/10.1515/commun-2016-0012.

Taddicken, M. and Wicke, N. (2019). 'Erwartungen an und Bewertungen der medialen Berichterstattung über den Klimawandel aus Rezipierendenperspektive'. [Expectations and evaluations of media coverage on climate change from the audience's perspective]. In: Klimawandel im Kopf. Studien zur Wirkung, Aneignung und Online-Kommunikation. Ed. by I. Neverla, M. Taddicken, I. Lörcher and I. Hoppe. Wiesbaden, Germany: Springer VS, pp. 145-172. https : //doi .org/10.1007/978-3-658-22145-4_6.

Taddicken, M., Wicke, N. and Willems, K. (2020). 'Verständlich und kompetent? Eine Echtzeitanalyse der Wahrnehmung und Beurteilung von Expert*innen in der Wissenschaftskommunikation'. [Comprehensible vs. competent? A real-time analysis of how experts are perceived and evaluated during science communication]. Medien E Kommunikationswissenschaft 68 (1-2), pp. 50-72. https://doi.org/10.5771/1615-634x-2020-1-2-50.

Urban, J. and Schweiger, W. (2014). 'News quality from the recipients' perspective'. Journalism Studies 15 (6), pp. 821-840. https://doi.org/10.1080/1461670x.2013.856670.

van der Wurff, R. and Schoenbach, K. (2014). 'Civic and citizen demands of news media and journalists'. Journalism \& Mass Communication Quarterly 91 (3), pp. 433-451. https://doi.org/10.1177/1077699014538974.

Voigt, J. (2016). Nachrichtenqualität aus Sicht der Mediennutzer: Wie Rezipienten die Leistung des Journalismus beurteilen können. [News quality from the perspective of the media user. How recipients judge journalistic performance]. Wiesbaden, Germany: Springer VS. https://doi.org/10.1007/978-3-658-12041-2.

Vowe, G. and Wolling, J. (2004). Radioqualität - was die Hörer wollen und was die Sender bieten: Vergleichende Untersuchung zu Qualitätsmerkmalen und Qualitätsbewertungen von Radioprogrammen in Thüringen, Sachsen-Anhalt und Hessen. [Radio quality - what listeners want and what broadcasters offer. A comparative investigation of the characteristics and evaluations of the quality of radio programs in Thuringia, Saxony-Anhalt and Hesse]. TLM-Schriftenreihe. Vol. 17. Munich, Germany: Kopaed.

Weischenberg, S., Malik, M. and Scholl, A. (2012). 'Journalism in Germany in the $21^{\text {st }}$ century'. In: Routledge communication series. The global journalist in the $21^{\text {st }}$ century. Ed. by D. H. Weaver and L. Willnat. New York, NY, U.S.A.: Routledge, pp. 205-219. https://doi.org/10.4324/9780203148679.

Wiehe, B. (2014). 'When science makes us who we are: known and speculative impacts of science festivals'. JCOM 13 (04), C02. https://doi.org/10.22323/2.13040302. 
Wissenschaft im Dialog (2014). Siggener Aufruf — Wissenschaftskommunikation gestalten. [Siggener call — creating science communication].

URL: https://www.wissenschaft-im-dialog.de/fileadmin/user_upload/Ueb er_uns/Gut_Siggen/Dokumente/Siggener_Aufruf_und_Leitlinien_2014.pdf.

- (2018). Wissenschaftsbarometer 2018. [Science Barometer 2018].

URL: https://www.wissenschaft-im-dialog.de/fileadmin/user_upload/Pro jekte/Wissenschaftsbarometer/Dokumente_18/Downloads_allgemein/Brosch uere_Wissenschaftsbarometer2018_Web.pdf.

- (2019). Science Barometer 2019. URL: https://www.wissenschaft-im-dialog. de /fileadmin/user_upload/Projekte/Wissenschaftsbarometer/Dokumente_19 /Downloads_allgemein/sciencebarometer_2019_brochure_web.pdf.

WissensCHaftsbarometer Schweiz (2019). WissensCHaftsbarometer Schweiz 2019. [Science Barometer Switzerland 2019]. URL: https://wissenschaftsbarometer .ch/wp-content/uploads/2019/10/WiB_2019_Brochure-1.pdf.

Wolling, J. (2004). ‘Qualitätserwartungen, Qualitätswahrnehmungen und die Nutzung von Fernsehserien'. [Quality expectations, quality perceptions and the use of television series]. Publizistik 49 (2), pp. 171-193. https://doi.org/10.1007/s11616-004-0035-y.

- (2009). 'The effect of subjective quality assessments on media selection'. In: Media choice: a theoretical and empirical overview. Ed. by T. Hartmann. New York, NY, U.S.A.: Routledge, pp. 81-101. https://doi.org/10.4324/9780203938652.

Zimmermann, M. and Jucks, R. (2018). 'How experts' use of medical technical jargon in different types of online health forums affects perceived information credibility: randomized experiment with laypersons'. Journal of Medical Internet Research 20 (1), e30. https://doi.org/10.2196/jmir.8346.

Authors

Nina Wicke is a Research Assistant and PhD candidate at the Institute for Communication Science at Technische Universität Braunschweig, Germany. Her main research fields include science communication, climate change communication and citizen science. She is interested in the audience's expectations and evaluations of different science communication formats.

E-mail: n.wicke@tu-braunschweig.de.

Monika Taddicken is a professor of Communication and Media Sciences at the Technische Universität Braunschweig, Germany. She received her PhD in communication research from the University of Hohenheim, Germany. She is currently working on the audience's perspective of science communication. She has also published several papers on computer-mediated communication, and survey methodology. E-mail: m.taddicken@tu-braunschweig.de.

\section{How to cite}

Wicke, N. and Taddicken, M. (2020). 'Listen to the audience(s)! Expectations and characteristics of expert debate attendants'. JCOM 19 (04), A02.

https://doi.org/10.22323/2.19040202.

(C) The Author(s). This article is licensed under the terms of the Creative Commons Attribution - NonCommercial - NoDerivativeWorks 4.0 License.

ISSN 1824-2049. Published by SISSA Medialab. jcom.sissa.it 